\title{
Author's accepted copy of \\ BLOGGING THE VIRTUAL: NEW GEOGRAPHIES OF DOMINATION AND RESISTANCE IN AND BEYOND RUSSIA
}

Sven Daniel Wolfe | SvenDaniel.Wolfe@unil.ch

Accepted for publication in

ANTIPODE

\begin{abstract}
:
Russia's accelerating authoritarian turn has not ignored the internet, and in recent years, the Russian state has clamped down on internet activities that diverge from the statist line, employing a variety of strategies to dominate online spaces. Nevertheless, oppositional voices flourish on the Russian internet, taking shape in independent blogs and videos. This paper explores three political bloggers through surveillant and resistance assemblages, making sense of this contestation through an interpretation of the Deleuzian virtual that underscores the emancipatory potential of online activities for producing more egalitarian configurations, but also taking stock of the ways that these technologies have increased domination. Encompassing the blurriness between digital and corporeal spaces, the paper contributes by revealing new geographies of contestation against state strategies to dominate the Russian internet. Overlapping with but not corresponding to Russian territorial boundaries, these dynamics highlight shifting spaces of power and resistance in the increasingly illiberal world.
\end{abstract}

Keywords: Surveillance, Blogging, More-or-less digital, Virtual, Authoritarianism, Russia

\section{Introduction: Negotiating authoritarian closures in Russia}

In July 2013, Maria Motuznaya answered an unexpected knock at her flat in Barnaul, a medium-sized Siberian city. She opened the door to find police officers with a warrant. They searched her flat, seized her phone and computer, and took her for questioning to the Directorate for Combating Extremism at the regional office of the Ministry of Internal Affairs. There, she learned her crime: saving pictures to an album on VK, Russia's Facebook clone and dominant social network (Motuznaya 2018a).

Over several years, Motuznaya had saved thousands of humorous and political images to her private VK folder (Golubev 2018). She was not an activist, but merely a politically progressive atheist fond of memes that ridiculed Orthodox believers and that mocked corruption within the Russian Orthodox Church (Motuznaya 2018b). For saving memes, Motuznaya was pressured into signing a confession and then charged with inciting hatred against protected groups. She was added to the government watchlist for terrorists and extremists, lost access to her bank account, and later fled to Ukraine (BBC Russkaya Sluzhba 2018). 
Motuznaya's story does more than highlight the increasingly repressive climate during Vladimir Putin's third and fourth terms as president (Gel'man 2015b; Treisman 2018). Her surveillance and arrest expose the intensification of efforts to enact authoritarian control within but also beyond the digital. These state strategies speak to the blurriness between digital and corporeal domains and, in so doing, they provide an opportunity to explore new geographies of domination and resistance. Beginning from this blurriness, I ask how the Russian authoritarian turn is expressed across these fluid, contingent, and more-or-less digital realities of contemporary life (Merrill et al. 2020). However, I focus neither on the online presence of political activists, nor on the connections between online opposition and mass protest in the street. Instead, I explore how people with a significant online presence negotiate these increasing closures to remain safe and continue their lives and livelihoods.

Thus, I follow three bloggers who framed themselves to greater or lesser degrees in opposition to dominant neoconservative and statist narratives. This distinction - between outright political activism and simply making an online living by producing content with various degrees of political engagement - results in a different perspective on Russia's ongoing authoritarian closures, one that underscores the decreasing possibilities for political discussion of any sort. Ultimately, each of these three bloggers attracted repressive state attention and, given that their livelihoods depended on their online activities, each attempted in their own ways to evade state pressures, stay safe, and continue working. Exploring the tactics they used provides nuance to discussions on the tension between safety and visibility facing online activists in authoritarian spaces (Lokot 2018). The paper contributes not only by identifying the tactics enacted by the bloggers, but also by exploring their outcomes across the blurry spectrum of the more-or-less digital, theorized from a perspective of Deleuzian virtuality that helps make sense of how and why the Russian state is working so fervently to control and punish online activity.

\section{The more-or-less digital RuNet through surveillant and resistance assemblages}

Our digital age, marked by nearly omnipresent computer technologies entwined with everyday life, has been described as the network society: where technological improvements allow horizontal, multidirectional, mass self-communication, with concomitant emancipatory potential (Castells 2015, 248). The new communications infrastructures that comprise the network society were seen by many as so-called liberation technology (Diamond 2010; Diamond and Plattner 2012), expanding political, social, and economic freedoms and potentially reorganizing more closed states towards transparency and democracy through the power of horizontal communication. In time, it has grown clear that these technologies can also expand state surveillance and control, strengthening global illiberalism through what Diamond (2019) ultimately called postmodern totalitarianism. This has been explored across a variety of authoritarian states, including China (Mackinnon 2011; Qiang 2019), Turkey (Topak 2017; 2019), and Iran (Akbari 2020; Golkar 2011; 2016), 
demonstrating how autocracies employ these technologies in variegated strategies to police and circumvent or suppress dissent.

It is not accurate, however, to frame these technologies solely as contributing to the entrenchment of authoritarian control, and it is possible in each of these cases to perceive a more nuanced struggle between domination and resistance, played out in novel domains. This requires an acknowledgement that digital practices produce new spatialities that do not necessarily correspond to bounded representations of national territory (Dodge and Kitchin 2003; Kitchin 1998; Thrift 1996). Working with these sensibilities necessitates a departure from conceptualizing digital and corporeal domains as different and divided, and instead moving towards an understanding of the more-or-less digital (Lim 2015; Merrill et al. 2020). This contingent hybridity opens up new avenues through which to explore struggles against state surveillance and control, while the authoritarian turn in contemporary Russia provides an opportunity to unpack some underexplored dynamics within these conflicts.

The Russian-language internet - colloquially knows as the RuNet - exemplifies the blurriness inherent in the more-or-less digital. RuNet is a broad term. It can refer to sites physically hosted within the territory of the Russian Federation; to sites with domain suffixes designating the countries as Russian-affiliated; or to Russian-language sites on the global internet, regardless of country. The RuNet has long been an outlet of free expression and a relatively safe environment for quasi-legal and illegal activities. Because the geography of the RuNet exists partially beyond the boundaries of Russian national territory, this relative freedom has persisted despite the context of increasing control driven by the authoritarian turn. Alongside this, two trends give the RuNet political relevance: first, after flirting with professional, independent journalism, traditional mass-audience media have increasingly come under control of state loyalists so that, despite modern trappings and state-of-the-art technologies, they function largely as mouthpieces for the state (Lipman, Kachkaeva, and Poyker 2018). In response, the RuNet has become a legitimate - though still minority - news source, and one of the few reliable places to find independent voices (Levada Center 2020). Second, internet use in Russia has risen sharply year-over-year, with a majority of the country now online: between 2008-2018, nationwide monthly use tripled from $24 \%$ to $72 \%$ - while daily internet users spiked from $12 \%$ to $64 \%$ of the population (FOM 2018). This is a story that enrolls immaterial politics, infrastructure modernization, and social change all at once: online and offline domains are not separate, but rather interdependent and mutually permeable.

The authoritarian turn has seen Russian law grow harsher towards activities that deviate from the statist line (Flikke 2016), and this extension of control includes the moreor-less digital spaces of the RuNet. These efforts at domination are complicated by the fact that the RuNet exists not only within Russian territory but also beyond it. Viewing authoritarianism not as territorially bounded but rather as a set of practices (Glasius 2018) helps explain how the Russian state both sees and attempts to dominate the RuNet, both within and beyond Russian territory. These processes of monitoring and control are part of 
what has come to be known as a surveillant assemblage (Haggerty and Ericson 2000), explaining how once-discrete security and information structures coalesce into a heterogeneous, all-encompassing, dynamic system. The surveillant assemblage is also at least partially flat, capturing enormous swaths of data on powerful and powerless alike, thereby - at least theoretically - leveling hierarchies to permit scrutiny of the powerful (Haggerty and Ericson 2000, 617). It is the combination of this potential scrutiny with the possibility of establishing new connections that drives state efforts to control the RuNet.

Surveillant assemblages are not stable structures, however. Instead, they are rhizomatic: contingent, always-becoming, and immanent with potentiality (Deleuze and Guattari 2013, 22). Nor are the individuals enrolled in this process without agency: as a surveillant assemblage coalesces around and identifies opposition forces, dissidents engage tactics to evade or thwart state efforts, which Akbari and Gabdulhakov (2019) conceptualize as a resistance assemblage. The dynamics between surveillant and resistance assemblages define much of the geography of the RuNet, intimately tied - but not limited - to spaces under Russian legal control, each perpetually agitating to reorder the rhizome in their favor, whether towards or against more consolidated state control.

State efforts to dominate the RuNet have occurred in three phases: first through technologies of filtering access, second through legal frameworks and improved technological controls, and finally through propaganda and direct attacks (Deibert and Rohozinski 2010). The root of modern surveillance in Russia is the System of OperativeInvestigative Measures (SORM), a set of state orders and technologies requiring telecommunication providers to allow the federal security services to monitor all traffic (Soldatov and Borogan 2015). SORM runs in concert with the Federal Service for the Supervision of Communications, Information Technology and Mass Media, or RosKomNadzor. The noun nadzor has several possible translations in English, giving a sense for the breadth of its responsibilities: "supervision," "control", "surveillance", and "policing". RosKomNadzor grants broadcasting licenses, maintains a list of blacklisted websites, and monitors all mass communications - including the RuNet - and there are allegations that the agency has exercised these powers against state opponents (Novaya Gazeta 2019).

Furthermore, recent amendments to the Russian Criminal Code have also contributed to the surveillant assemblage. Passed after Pussy Riot's infamous anti-Putin cathedral performance (Steinholt 2013; Voronina 2013), Article 148 outlawed public expressions injurious to the feelings of religious believers, while Article 282 forbade the incitement of hatred against protected groups (OUKRF 2020). These new laws have been applied subjectively, snaring people for private behavior (such as what happened to Maria Motuznaya), or targeting political opponents (Kosovan 2016). Another law forces any site with more than 3000 daily views to register with RosKomNadzor (BBC 2014), and any organization, journalist, or blogger that receives international funding must register as a foreign agent (Roth 2019; Skibo 2017). The aim is to chill free expression by reducing or 
eliminating online anonymity, while diminishing the introduction of non-state narratives by weakening or destroying international linkages.

One of the problems for the increasingly authoritarian Russian state is the fact that its legal reach is limited to national borders. This is not to say that extralegal activities do not occur, but rather to emphasize that many resistance assemblages rely on the RuNet existing beyond Russian territorial control. To combat this, a new law was passed to require that foreign internet companies use servers located within Russia (Karnaukh 2015). This ensures that RosKomNadzor commands information flows and that SORM provides access to the security services. An understanding of the more-or-less digital helps explain these state strategies to extend the surveillant assemblage: the RuNet is simultaneously immaterial and yet inescapably tethered to physical infrastructures, just as it is borderless but also governed by laws within state borders. This complicates the idea that surveillance regimes are detached from territorial boundaries (Murakami Wood 2013) and provides a potential explanation for certain state strategies to regulate online spaces.

\section{Informational autocracy and the virtual}

Despite the increase in authoritarian practices, the Russian state does not engage in crude mass repression. Instead, it is an informational autocracy (Guriev and Treisman 2015; 2019), wherein leadership is presented as competent and benevolent, and outright repression is kept to a minimum. Control over the media landscape is key to this strategy, since the spread of dissenting perspectives threatens the state's presentation of reality. Combined with targeted repression of troublesome individuals and the violent suppression of street protest, Russian informational autocracy has been adept at monopolizing information in order to sustain itself. Since traditional media is largely controlled, the internet remains the most credible potential threat to the state's comparatively unified informational front. This threat applies even to members of the Russian elite, where exposure to diverse perspectives via the internet correlated with more positive attitudes towards the west, as opposed to elites whose media diet consisted of state-controlled sources (Rivera and Bryan 2019; Tkacheva 2019). Yet it is imperative that restrictions are not seen as too draconian, so a limited amount of relatively open internet communication is tolerated in order to mollify the population. Known as networked authoritarianism (MacKinnon 2011), this tolerance serves both as a release valve for social pressures and as a means of defusing criticism, because citizens do have the right to communicate and complain. At the same time, this is a precarious freedom, fluid and subject to disappearing if an invisible line is crossed (Glasius et al. 2018). Many people who oppose the state have become skilled at negotiating these relatively free spaces left open in informational and networked autocracies.

There is a tension, however, between maintaining these gaps in order to sustain informational autocracy (thereby avoiding the costs and consequences of naked repression), and eliminating them because of the potential threats they enable. Oppositional figures are adept at exploiting this tension. Thus, resistance assemblages coalesce in new ways to evade detection and punishment, while the surveillant assemblage polices the gaps and the 
increase in authoritarian practices reduces the gaps. In this way, individuals - including the three bloggers featured here - continue to voice oppositional discourses throughout the shrinking free spaces of the more-or-less digital.

The terms digital, online, and virtual are often used synonymously to refer to interactions mediated through internet technologies, but they are marked by important differences. Thinking through Deleuze, it is the virtual that most helpfully transcends the illusion of spatial dualism between online and offline realms, engaging a more-or-less digital sensibility but traveling beyond it. Whereas the virtual often refers to a simulated, parallel version of corporeal reality, the Deleuzian virtual is very real (Shields 2003, 22). It is ripe with potentiality, contingent, and always-becoming (Deleuze 2014; Doel 1996; 2000). The virtual is rhizomatic, referring to the subterranean tubers that grow horizontally and produce both roots and shoots, and are seen as both connected and heterogenous (Deleuze and Guattari 2013, 34). Rhizomatic thinking helps make sense of the constant tension, dynamism, and immanent potential roiling through the virtual as it coalesces, breaks down, and recombines into various surveillant and resistance assemblages.

Continuing with Deleuze, the Russian state aspires to the arborescent: towering, hierarchical, and determinate. The struggle, then, is one where state actors work to impose hierarchy, control, and ontological rigidity on the virtual, trying to nail the rhizome into place. These tensions between fixity and flux can be rendered visible through a view towards strategies and tactics (de Certeau 2011, 36-38), where the state's rational calculus exercised from positions of power takes shape as the surveillant assemblage. In response, this begs the question of what resistance tactics could be engaged by individuals as they operate opportunistically within parameters imposed by the state.

This interpretation via strategies and tactics is complicated by the ways in which the RuNet defies traditional territorial boundaries. Following de Certeau, since the state operates from a delimited place - here, its national territory, where it exerts legal authority - strategies to dominate the RuNet are actually battles to expand state power beyond the borders of its legal remit. These are attempts to extend the territory of the Russian state virtually, yes, but no less real. Within this context, tactics are the individual efforts to resist these strategies of extending state power, of fixing the virtual. The empirical sections of this paper explore two of these tactics, as expressed in the activities of three bloggers who attempted to evade virtual state domination. Their challenges, successes, and failures illustrate the decreasing spaces for expression and opposition within Russia's informational autocracy, while highlighting the need for sustained resistance and solidarity, both domestically and internationally.

\section{Working in the authoritarian virtual}

Contemporary Russia is not friendly to political opposition: stories of harassment, assault, imprisonment, or murder are common and, on average, less than a third of Russians think a protest of any size is possible in their city (Levada Center 2019). Despite this, vibrant oppositional cultures do exist, though they take ambiguous shapes in order to evade state 
repression (Fröhlich and Jacobsson 2019). Yet street actions remain challenging and often dangerous, which has caused opposition cultures to thrive in the worlds of art and music (Jonson 2015). There are debates about the distinctions between countercultures, protest, and opposition (Gabowitsch 2017), but here, I define opposition as action taken against the state or in defiance of state narratives, and in this sense, opposition flourishes on the RuNet. I do not engage in definitional debates about the Russian opposition (Gel'man 2015a; 2005; White 2015), nor do I believe that 'the opposition' is a coherent group.

In parallel with the diminishing opportunities for street protest, there exists the potential for virtual opposition to engender political change (Gainous, Wagner, and Ziegler 2018). There is a wealth of multidisciplinary literature regarding online opposition, but the majority of studies seem to privilege the connections between social media and street protest (see Howard and Hussain 2013; Jost et al. 2018; Merrill and Pries 2019; Penney and Dadas 2014; Ruijgrok 2017, and for Russia in particular, Radchenko, Pisarevskaya, and Ksenofontova 2012). Clearly, mass in-person protest occupies a coveted spot atop the hierarchy of resistance scholarship, and while I am sympathetic to many of these studies, I disagree with the implicit assumption that virtual opposition only matters so long as it spurs physical action. This is not an acknowledgment that electronic civil disobedience is fundamentally self-defeating (Vlavo 2012), but rather an argument that the virtual actually does contains the potential to destabilize state hierarchies. The rhizome is alwaysbecoming, and within resistance assemblages there is always the possibility for actors to reconfigure relations in ways that diminish or even eliminate autocratic power. That the state punishes dissent on the RuNet suggests that Russian informational autocracy is more vulnerable than it might seem, and that the authorities take the virtual seriously. This paper is grounded in the premise that we should take the virtual seriously as well.

There is a huge amount of political and oppositional activity on the Russian internet, but rather than focus on opposition figures outright, I focus on bloggers. There are multitudes of bloggers in Russia working at different scales (Gorny 2009), and blogging has grown to resemble a slick and profitable media industry instead of the amateurish content that the name might connote. Blogging means creating and maintaining high-quality, engaging content across numerous internet platforms, and the financial rewards for popularity can be immense. The three bloggers featured here might not be considered activists or opposition figures, but they were targeted for state repression because they marketed themselves in various ways against the state. Starting from Russia's authoritarian turn after Vladimir Putin's return to the presidency, I followed the bloggers from 2011 2019 by engaging a virtual ethnographic sensitivity (Hine 2017) that eschews territorial boundedness and instead foregrounds flows, connections, and mediated interactions (Hine 2000, 64).

All three bloggers produced written, photographic, and video content on a variety of platforms, popular and provocative enough to warrant attention from the authorities, and all three engaged tactics to evade state repression. Over the course of the study period, I traced their activities and collected their content, but did not participate in the public 
geographies of their social media followings (Kitchin et al. 2013). Nor did I collect material posted by private individuals to these public forums, following robust privacy and anonymity protections (franzke et al. 2020), and out of concern for potential downstream effects due to my highlighting their statements (Williams, Burnap, and Sloan 2017). Instead, I focused only on posts by the three bloggers - public figures - who used the internet to publicize and promote their chosen issues and, also, themselves.

To understand each blogger's online presence and oppositional activity, I identified the sites where each was most popular: Twitter, YouTube, Telegram, Instagram, and VK. With a custom-built tool written in Python, I extracted blogger-generated text from these sites to create an archive. I used qualitative data analysis software to code this archive, but had to omit visual material, as it was not feasible to catalog thousands of videos. Instead I watched roughly $20 \%$ of the total videos and judged the remainder by their titles and descriptions. To approximate how political each blogger was, I coded the archive on a 4point scale: purely, partially, slightly, and not at all political, with the understanding that this rating is subjective and open to dispute. In future projects I plan to employ automated sentiment analysis but this is not an unproblematic solution either (Giachanou and Crestani 2016). As the bloggers are public figures, I augmented the archive with relevant traditional media coverage, and then triangulated these online methods with conversations with six Russians (three activists, two citizen journalists, and one mainstream reporter). These interactions were part of a separate project that did not focus on Russian opposition. Instead, the themes discussed here emerged inductively over time, parallel to the original project. In all cases, participants' personally identifiable information was anonymized from the start, and no material links people to their statements. The reason for this caution is due to ethical and safety concerns when doing research in authoritarian contexts (Glasius et al. 2018). Overall, my aim was to synthesize a picture of each blogger: their reach, the depth of their oppositional engagement, and what happened to them in the context of Russia's authoritarian turn.

Despite their status as public figures, analyzing these bloggers raises ethical questions: as opposed to private social media users, these people make a living from their work and wish it to be distributed widely - indeed, they routinely exhort their audiences to share their content. The question is whether my attention here - focusing on an oppositional posture - could lead to harm. This is a legitimate risk and I cannot guarantee that this discussion will not prompt a response from the state, particularly as they are already visible to the security services - and one of them actually is in prison. However, I contend that ignoring their stories is also unacceptable, because cases like these are crucial for understanding strategies of suppression and tactics of resistance in contemporary Russia. Given that the RuNet does not conform to territorial boundaries, these insights apply outside the country as well, and might hold value in other situations where authoritarian practices seek to dominate the virtual. 


\section{The commodification of opposition and the tactic of escape}

Kamikadzedead is the pseudonym of a blogger who has grown popular as a vociferous critic of the state. His YouTube channel is the hub of his online presence and, by 2019, Kamikadzedead had over 1.7 million YouTube subscribers and 1,309 videos. His presence elsewhere was smaller, with about 95,000 followers each on Twitter and VK., and his activity on other platforms generally serves to drive viewers to his videos. Overall, I coded his content as $94 \%$ purely political, $4 \%$ partially political, and $2 \%$ apolitical (mostly vacation snapshots to his 29,000 Instagram followers).

Kamikadzedead presents himself in opposition to all scales of the state, and his videos target everyone from the president down to petty peripheral bureaucrats. His outspoken style has earned a loyal following and he often frames his arguments around inequalities by demonstrating the effects of corruption (for typical examples, see Kamikadzedead 2019; 2020). An activist explained: "I like that he's not scared to say what's happening. It gives a good feeling, like you're not the only one, like you're not crazy." This statement points to two ways that Kamikadzedead defies informational autocracy: first, his videos propagate alternative discourses, and second, the comments section below each video provides space to nourish oppositional communities. In this way, Kamikadzedead's videos helped this activist locate herself within the gaps of informational autocracy.

At the same time, Kamikadzedead is not a political activist in the traditional sense. Instead, blogging is his business, and the product he sells is outraged political commentary. It is unclear how much money he makes, because YouTube's monetization deals are opaque and tailored to each creator's clout as measured by viewer engagement (Caplan and Gillespie 2020). Nevertheless, it is reasonable to assume that his audience of millions allows him to command high prices for advertising. Since he presents himself as oppositional, this business imperative does not constrain his political posture. Fittingly, he pitches products and services aimed at the dissident class, for instance VPN software to evade state surveillance, or legal services to avoid mandatory military service. Nevertheless, financial logics do affect his behavior, notably in the pace of his production. One of the challenges of blogging as a business is the pressure to create regular content, particularly as prolific creators tend to get paid more (Caplan and Gillespie 2020). Kamikadzedead's prolific publishing schedule is only possible with the help of his viewers, who submit homemade videos - often of crumbling local infrastructures - for him to feature and discuss. These videos receive hundreds of thousands of views and Kamikadzedead always acknowledges the person who submitted. These interactions offer more than a glimmer of fame: they nourish an audience-performer bond while shedding light on regions and topics that remain under-investigated by traditional media. Kamikadzedead inhabits a space that is both explicitly oppositional but also audience-dependent like any other content creator.

State authorities have not ignored Kamikadzedead's popularity, and his comment sections are routinely filled with cookie-cutter pro-government messages. More insidiously, Kamikadzedead has noticed that likes and views often disappear from his videos. These are the currency of the YouTuve and removing them reduces revenue, but this could only 
happen if the platform were coordinating with authorities. While this is possible, given the state's access to servers in Russia, there exists no proof of this specific. Still, Russian YouTube is often forced to fulfill requests from RosKomNadzor to delete videos or block entire channels (RBC 2017).

These attacks on Kamikadzedead's livelihood can be explored by thinking through the surveillant assemblage. These processes capture online activity, abstracting humans from their bodies and territorial locations, and then reassembling flows into a "decorporealized body, a 'data double' of pure virtuality," (Haggerty and Ericson 2000, 611). Just as the corporeal body can be monitored and controlled, so too is the data double subject to surveillance for marketing and security. Though tethered, the data double exists separately from the corporeal body, in the sense that one can engage in political activity while the other does not. This explains why the state targeted Kamikadzedead's data double for repression, but left his corporeal body in peace. Yet virtuality transcends binary limitations and sees the blurry interconnectedness between the data double and corporeal body. In keeping with this, once Kamikadzedead's channel passed one million subscribers, state authorities charged him for violation of Article 110 of the Russian Criminal Code, which outlaws driving someone to suicide - the result of a poorly done joke in an early video. Worried for his physical safety, Kamikadzedead fled Russia (TV Rain 2017). He explained:

"I got scared that at 6 in the morning, someone would break into my flat. Some Nazi or religious extremist, or - much worse - a Putin supporter, and that they would disappear me." (Nemtsova 2018)

This is the tactic of escape: removing one's corporeal body from potential harm, evoking the classic concept of exit / voice / loyalty (Hirschman 1970; 1993). Though thoroughly reworked in recent decades, at its heart this notion illuminates how an individual, when faced with unacceptable circumstances, can choose either to leave, to speak up, or to display loyalty, and it has been employed to explain a range of economic and political phenomena. Michaelsen (2018) carries this concept into the era of digital protest, explaining the strategies employed by repressive states to suppress dissent beyond territorial borders. Distinguishing between vertical voice (speaking to power) and horizontal voice (forging social links to create shared identities), Michaelsen demonstrates that horizontal voice can continue even after exit. The RuNet allows Kamikadzedead to continue his business of political outrage from abroad, so that his horizontal voice still carries the potential to reorder the rhizome. Yet repressive strategies have not ceased since he fled, and he recently closed his comment sections to all participants - a move that could alienate viewers who come looking for community. 


\section{Synopticism and the tactic of visibility}

If Kamikadzedead attempted a variation on exit, then Ilya Varlamov employed a variation on voice. Varlamov sits at the heart of a bespoke online media empire that produces video and written content across numerous platforms, and he is credited by Forbes as a dollar multimillionaire (Zhitkova 2019). The core of Varlamov's activities is urban analysis, though he sometimes strays into political commentary, and his videos are slick and modern with high production values and consistent branding. The videos are formulaic and enjoyable: he explores a city and explains what is done well or poorly. He delights in traveling abroad to find examples of good urban planning, and while he sometimes criticizes foreign cities, the bulk of his infamous grumpiness is directed at Russian urbanity, which he usually lampoons with ill-concealed glee (for typical examples see Varlamov 2020; 2019).

By the end of 2019, Varlamov had 1.17 million subscribers and more than 900 videos on YouTube, with 310,000 followers on Twitter and 128,000 tweets. He tweets prolifically, filling the microblogging space with jokes and complaints. He also maintains a text blog and several Telegram channels, all of which provide something like an independent news service. To create his written content, Varlamov - like Kamikadzedead - sources contributions from his audience and then adds his own commentary. At its best, the news service aspect of his work (much of it curated by staff rather than Varlamov) is close to citizen journalism, albeit attached to a business model that enriches Varlamov Inc. His fans do not seem to mind: "Varlamov isn't responsible to anyone so he can go where he wants and say what he wants," a journalist told me. "I think it's wonderful that he's making good money. Why shouldn't he?" This journalist followed Varlamov on Twitter, YouTube, and Telegram, and explained that Twitter was for on-the-road updates, YouTube for long-form pieces, but Telegram was like a local news service that he checked several times a day. That a mainstream journalist would value Varlamov's Telegram channel as a news source speaks volumes about the gaps in Russia's traditional media landscape. This journalist is not alone in his views: by 2019 Varlamov had nearly 300,000 followers on Telegram.

Though he is politically liberal, Varlamov is less overtly oppositional than Kamikadzedead. In this study he was coded as only $47 \%$ political overall, only sometimes bringing in politics as a subset of his typical discussions on urban problems. Even with this circumspect posture, however, Varlamov sometimes runs afoul of the authorities. These incidents typically provoke him to make a few transparently political videos. For example, in the run-up to the 2018 World Cup, Varlamov filmed a series that explored urban preparations in every host city. Usually he films without incident, but in Volgograd he was stopped twice: once by police for recording at a tram stop, and once by the federal security services for filming the renovated central train station. Unable to document the city's improvements, Varlamov instead filmed broken roads, destitute parks, and crumbling buildings, complaining about the idiocy of the authorities (Varlamov 2018b).

A more dramatic encounter occurred while Varlamov was filming a live television interview via mobile video on a Moscow street. The nationwide audience watched in realtime as officers approached Varlamov on camera from behind, interrupted him mid- 
sentence, and shut down the interview. He was detained for several hours but then, to his surprise, released without charges or explanation. He then filmed a political video where he credited his release to his status as a public figure: because he was famous, and arrested on camera, other famous and influential people raised an immediate outcry (Varlamov 2018a). This is the tactic of visibility, leveraging the public gaze to secure safety. It is a form of synopticism - an inversion of panoptical surveillance - wherein large numbers of people focus on the same thing (Hier 2003; Haggerty and Ericson 2007). As a famous blogger, Varlamov he was standing in the center of the synoptic gaze when he was arrested, and it was the immediate outcry originating from this position that secured his release.

\section{Fragility and the failure of tactics}

One of the problems with the tactic of visibility is that the synoptic gaze is not universally available. In a street protest, for instance, average people might take advantage of a synoptic defense relatively easily, but online this calculus changes to favor the famous. Alexander Valov, founder and chief editor of BlogSochi, demonstrates this problem with the tactic of visibility, as he failed to engage synoptic safety due to his limited fame.

BlogSochi was a local news service that highlighted the Sochi region's natural beauty and outdoor recreation options, but grew to investigate environmental crimes and participate in local politics. It exists now only in shards, scrubbed from the internet after Valov's arrest. This ephemerality posed a methodological challenge for research, as I was wholly unprepared for BlogSochi's disappearance. What remained to me were the few articles I had saved locally, the notes I had taken, and my imprecise memory. Later, I discovered traces in the Internet Archive Wayback Machine, but these were only incomplete snapshots. When appropriate, I used conversations with Sochi residents to complement these missing materials.

BlogSochi began as Valov's actual blog, and although it grew in ambition and professionalism, it never lost its slightly homemade feel nor ventured beyond its home region. Valov's hub was his blog, but he was also active on VK and eventually on YouTube. In 2017, he proudly announced that he had 5.7 million total video views, 465,000 monthly viewers, and 3000 subscribers. These numbers might not compare to Varlamov and Kamikadzedead, but they represent significant regional attention, as Sochi had 438,000 residents in 2019 (Russian Federal State Statistics Service 2020). Moreover, BlogSochi's relatively small audience, local focus, and hometown aesthetic gave it an unmatched authenticity. Sochi residents explained that Valov's native status made the site trustworthy, particularly in comparison to national outlets.

Valov's investigations of the preparations for the 2014 Winter Olympics boosted his regional fame, as he gave voice to locals whose complaints were ignored by traditional media. Capitalizing on this attention, he began professionalizing BlogSochi by developing a logo, selling advertisements, and sponsoring local events, even as he adopted more of an oppositional posture. In 2016, after showing the post-Olympic sites to American journalists, Valov was arrested by the federal security services and accused of organizing illegal protests 
(Kravchenko 2016). Unlike Varlamov, whose fame helped secure his rapid release, Valov was imprisoned for five days. When released, he filed a complaint with the European Court of Human Rights (Kavkazky Uzel 2017), and started using BlogSochi for more overt oppositional politics. He did not attempt the tactic of escape, likely because his work was so locally grounded that it would be impossible to continue from afar, to say nothing of his love for Sochi.

In 2017, Valov discovered a seafront home with a private swimming pool built on a section of public beach. This was an illegal seizure of public land. He photographed the pool and published an investigation on BlogSochi, challenging municipal authorities to uphold the law. The homeowner, however, turned out to be an influential senator from Moscow with a vacation home in Sochi. The senator responded to BlogSochi's allegations by accusing Valov of insulting his honor and trying to solicit bribes. The words of a senator carry more weight than those of a blogger, so the police came to arrest Valov at his flat. Valov refused to open the door and began livestreaming to BlogSochi from his phone, an attempt to engage the tactic of visibility and the security of the synoptic gaze.

Though both arrests took place live, there were major differences between Varlamov and Valov that account for the divergence in their outcomes. Whereas Varlamov was clearly visible to his audience, Valov filmed in the dark as the police cut the electricity to his flat. Next, police destroyed Valov's metal security door with a power saw, and the small live audience heard the sounds of physical struggle (see Gostev 2018). Valov was arrested, charged with extorting a federal official, and imprisoned, and there are allegations that he has been assaulted in jail (CPJ 2018; Popkov 2018). Despite legal challenges, some small local protests, and scattered media attention, Valov was sentenced to six years in a penal colony (Kozkina 2018).

BlogSochi thrived because Valov was a Sochi local, but this regionality also limited his ability to engage the tactic of visibility. Ultimately, his audience was too small to engage a successful synoptic defense. Valov was punished for trying to exercise vertical voice, exposing the lawbreaking of the powerful, but his horizontal voice still threatened informational autocracy so long as BlogSochi continued to exist. For this reason, BlogSochi was swiftly deleted from the internet, demonstrating the purpose of forcing websites to register with RosKomNadzor, and the value of tethering the RuNet to physical infrastructures within Russia. Valov's investigations exist now as incomplete snapshots in scattered spaces overlooked by authorities or perhaps out of their reach. The BlogSochi domain is for sale, and the VK page has been transformed into pablum with articles like " 50 best things about visiting Sochi!"), and Valov remains in prison.

\section{Conclusion: Blogging to reorder the rhizome}

The blurriness of the RuNet encompasses "both the virtual and its actualization simultaneously, without there being any assignable limit between the two" (Deleuze and Parnet 2007, 149). The bloggers featured here made their living in this blurriness, working within the gaps left by the tensions inherent in informational autocracy (Murakami Wood 
2013). These gaps - between the need to maintain the semblance of free speech and the need to reduce the potential threat of that freedom - are filled with the immanent potential to reorder the rhizome away from authoritarian control and towards more egalitarian configurations. Exploring these gaps is salient both within and beyond Russia, given the increase in authoritarian practices around the globe (Guriev and Treisman 2019).

The bloggers were not activists or opposition figures in the traditional sense (Lokot 2018), but rather presented themselves within an oppositional grammar, whether in political, urban, or environmental terms, while carving lucrative niches in Russia's growing internet market. All three bloggers attempted tactics for safety after their oppositional postures garnered the attention of state security services. In following their stories, this paper demonstrates how the RuNet is neither liberation technology (Diamond 2010; Diamond and Plattner 2012) nor a tool of state repression (Golkar 2011; Pospieszna and Galus 2019), but rather something in between, fluid and contingent.

In order to maintain informational autocracy, the surveillant assemblage flagged the bloggers for repression once their vertical and/or horizontal voices grew too loud. Depending on their positionalities, each of them faced different options and outcomes: escaping, engaging the synoptic protection granted to fame, or imprisonment. Two of the three were able to continue working despite repressive state attention, demonstrating the latitude for emancipatory potential within Russian informational autocracy, as well as the ability to participate in the RuNet even outside Russian territory. The gaps for this kind of opposition are shrinking, however: there has been a string of state attempts to dominate the RuNet (Novie Izvestiya 2017), working not only through governing institutions like RosKomNadzor and surveillance technologies like SORM, but also through more extreme isolationist strategies that mirror the shutdowns and firewalls of Iran or China (Akbari 2020; Qiang 2019). Thus, building on President Putin's longstanding criticism of the internet as a $\mathrm{ClA}$ project and a corrupting foreign influence (MacAskill 2014), lawmakers recently approved a so-called "sovereign internet" bill that attempts to make the RuNet correspond exactly to Russian territorial boundaries (Ilyushina 2019). Framed as a matter of national security, the sovereign internet bill not only establishes greater state power over the RuNet, but also grants authorities the ability to sever links to the internet outside Russia, creating a totally independent network (Lipman and Lokot 2019). This would fracture the RuNet, cutting the sovereign section away from Russian-speaking parts in the world outside Russian state control. At the same time, the expectations of an increasingly-online population put pressure on the authorities to grow the digital economy and boost international connectedness (Blanutsa 2019; Dobrolyubova, Alexandrov, and Yefremov 2017). It is not clear how informational autocracy can survive under this tension, and this may be one of the explanatory factors behind the recent closures in Russia due to the rise in more nakedly authoritarian practices.

The struggles on the RuNet are redrawing national and global geographies through blurry and contingent processes that are tethered to material infrastructures within traditional territorial boundaries, but that also transcend them. This virtuality defies the 
imaginary binary between digital and corporeal, and contains the immanent potential to restructure the rhizome away from authoritarian control. Though embattled, the RuNet still harbors vibrant oppositional cultures, and the bloggers featured here all made a name for themselves through an oppositional posture. Put another way, they thrived within the relatively free spaces afforded by informational autocracy, and made a living by propagating alternative narratives that could destabilize autocratic control. With a view towards the shrinking spaces for free political expression, their stories shed light on some of the tactics used to evade repression - not just in Russia but in an alarming number of states worldwide. Within this global authoritarian turn, it is imperative to analyze both state strategies for more-than-digital domination and the tactics through which individuals attempt to reorder the rhizome and resist.

\section{Acknowledgements:}

I would like to thank Anastassia Shaitarova for writing the Python tool that made large-scale data collection possible, the anonymous reviewers who helped knock the argument into shape, Dave Featherstone for professional support in a challenging year, and the organizers of a conference at the University College London Urban Laboratory, where I presented an early version of this paper.

\section{Literature}

Akbari, Azadeh. 2020. "Follow the Thing: Data." Antipode 52 (2): 408-29. https://doi.org/10.1111/anti.12596.

Akbari, Azadeh, and Rashid Gabdulhakov. 2019. "Platform Surveillance and Resistance in Iran and Russia: The Case of Telegram.” Surveillance \& Society 17 (1/2): 223-31. https://doi.org/10.24908/ss.v17i1/2.12928.

BBC. 2014. “'Draconian' Russian Net Law Enacted.” BBC News, August 1, 2014, sec. Technology. https://www.bbc.com/news/technology-28583669.

BBC Russkaya Sluzhba. 2018. "Accused of extremism for memes, Maria Motuznaya leaves

Russia.” BBC News Russkaya Sluzhba. August 6, 2018.

https://www.bbc.com/russian/live/institutional-45098631.

Blanutsa, V. I. 2019. “Territorial Structure of the Russian Digital Economy: Preliminary

Delimitation of Smart Urban Agglomerations and Regions.” Regional Research of Russia 9 (4): 318-28. https://doi.org/10.1134/S207997051904004X.

Caplan, Robyn, and Tarleton Gillespie. 2020. "Tiered Governance and Demonetization: The Shifting Terms of Labor and Compensation in the Platform Economy." Social Media + Society 6 (2): 2056305120936636. https://doi.org/10.1177/2056305120936636.

Castells, Manuel. 2015. Networks of Outrage and Hope: Social Movements in the Internet Age. 2 edition.

Cambridge, UK; Malden, MA: Polity.

Certeau, Michel de. 2011. The Practice of Everyday Life. Berkeley: University of California Press. CPJ. 2018. “Aleksandr Valov.” Committee to Protect Journalists. November 1, 2018.

https://cpj.org/data/people/aleksandr-valov/index.php. 
Deibert, Ronald, and Rafal Rohozinski. 2010. "Control and Subversion in Russian Cyberspace." In Access Controlled, edited by Ronald Deibert, John Palfrey, Rafal Rohozinski, and Jonathan Zittrain, 15-34. Cambridge, MA: The MIT Press. https://doi.org/10.7551/mitpress/8551.003.0007.

Deleuze, Gilles. 2014. Difference and Repetition. 2nd Revised edition. London ; New York: Bloomsbury Academic.

Deleuze, Gilles, and Felix Guattari. 2013. A Thousand Plateaus. London: Bloomsbury Academic. Deleuze, Gilles, and Claire Parnet. 2007. Dialogues II. Translated by Hugh Tomlinson and Barbara Habberjam. New York: Columbia University Press.

Diamond, Larry. 2010. "Liberation Technology.” Journal of Democracy 21 (3): 69-83. https://doi.org/10.1353/jod.0.0190.

. 2019. “The Threat of Postmodern Totalitarianism.” Journal of Democracy 30 (1): 20-24. https://doi.org/10.1353/jod.2019.0001.

Diamond, Larry, and Marc F. Plattner. 2012. Liberation Technology: Social Media and the Struggle for Democracy. JHU Press.

Dobrolyubova, Elena, Oleg Alexandrov, and Alexey Yefremov. 2017. "Is Russia Ready for Digital Transformation?” In Digital Transformation and Global Society, edited by Daniel A. Alexandrov, Alexander V. Boukhanovsky, Andrei V. Chugunov, Yury Kabanov, and Olessia Koltsova, 431-44. Communications in Computer and Information Science. Cham: Springer International Publishing. https://doi.org/10.1007/978-3-319-69784$0 \_36$.

Dodge, Martin, and Rob Kitchin. 2003. Mapping Cyberspace. 1 edition. London ; New York: Routledge.

Doel, Marcus A. 1996. "A Hundred Thousand Lines of Flight: A Machinic Introduction to the Nomad Thought and Scrumpled Geography of Gilles Deleuze and Félix Guattari." Environment and Planning D: Society and Space 14 (4): 421-39. https://doi.org/10.1068/d140421.

. 2000. "Un-Glunking Geography: Spatial Science after Dr Suess and Gilles Deleuze." In Thinking Space, edited by Mike Crang and Nigel Thrift, 1 edition, 117-35. London ; New York: Routledge.

Flikke, Geir. 2016. "Resurgent Authoritarianism: The Case of Russia's New NGO Legislation." Post-Soviet Affairs 32 (2): 103-31. https:/ / doi.org/10.1080/1060586X.2015.1034981.

FOM. 2018. "Internet in Russia: Dynamics of Penetration. Winter 2017-2018.” April 4, 2018. https:// fom.ru/SMI-i-internet/13999.

franzke, aline shakti, Anja Bechman, Michael Zimmer, Charles Ess, and Association of Internet Researchers. 2020. "Internet Research: Ethical Guidelines 3.0." Association of Internet Researchers. https://aoir.org/reports/ethics3.pdf.

Fröhlich, Christian, and Kerstin Jacobsson. 2019. "Performing Resistance: Liminality, Infrapolitics, and Spatial Contestation in Contemporary Russia." Antipode 51 (4): 114665. https://doi.org/10.1111/anti.12529.

Gabowitsch, Mischa. 2017. Protest in Putin's Russia. Cambridge; Malden: Polity Press.

Gainous, Jason, Kevin M. Wagner, and Charles E. Ziegler. 2018. "Digital Media and Political Opposition in Authoritarian Systems: Russia's 2011 and 2016 Duma Elections." Democratization 25 (2): 209-26. https://doi.org/10.1080/13510347.2017.1315566. 
Gel'man, Vladimir. 2005. "Political Opposition in Russia: Is It Becoming Extinct." Russian Social Science Review 46 (4): 5-30. https://doi.org/10.1080/10611428.2005.11065185.

—. 2015a. "Political Opposition in Russia: A Troubled Transformation." Europe-Asia Studies 67 (2): 177-91. https://doi.org/10.1080/09668136.2014.1001577.

. 2015b. Authoritarian Russia: Analyzing Post-Soviet Regime Changes. Pittsburgh: University of Pittsburgh Press.

Giachanou, Anastasia, and Fabio Crestani. 2016. "Like It or Not: A Survey of Twitter Sentiment Analysis Methods.” ACM Computing Surveys 49 (2): 28:1-28:41.

https://doi.org/10.1145/2938640.

Glasius, Marlies. 2018. "Extraterritorial Authoritarian Practices: A Framework." Globalizations 15 (2): 179-97. https://doi.org/10.1080/14747731.2017.1403781.

Glasius, Marlies, Meta de Lange, Jos Bartman, Emanuela Dalmasso, Aofei Lv, Adele Del Sordi, Marcus Michaelsen, and Kris Ruijgrok. 2018. Research, Ethics and Risk in the Authoritarian Field. Cham: Springer International Publishing. https://doi.org/10.1007/978-3-31968966-1.

Golkar, Saeid. 2011. "Liberation or Suppression Technologies? The Internet, the Green Movement and the Regime in Iran Liberation or Suppression Technologies? The Internet, the Green Movement and the Regime in Iran." International Journal of Emerging Technologies and Society 9 (1): 50-70.

. 2016. "Manipulated Society: Paralyzing the Masses in Post-Revolutionary Iran." International Journal of Politics, Culture, and Society 29 (2): 135-55. https://doi.org/10.1007/s10767-015-9208-0.

Golubev, Sergey. 2018. “One Girl Wasn't Taking It Seriously and She Got a Three Year Sentence." How a Barnaul Resident Was Coerced into Confessing.” Mediazona. June 24, 2018. https://zona.media/article/2018/07/24/frolova.

Gorny, Eugene. 2009. "Understanding the Real Impact of Russian Blogs.” Russian Analytical Digest 69 (9): 8-11.

Gostev, Alexander. 2018. 'FSB versus a 'difficult man.' Arresting the founder of BlogSochi." Radio Svoboda. February 6, 2018. https://www.svoboda.org/a/29017771.html.

Guriev, Sergei, and Daniel Treisman. 2015. "How Modern Dictators Survive: An Informational Theory of the New Authoritarianism.” Working Paper 21136. National Bureau of Economic Research. https://doi.org/10.3386/w21136.

—. 2019. "Informational Autocrats." Journal of Economic Perspectives 33 (4): 100-127. https://doi.org/10.1257/jep.33.4.100.

Haggerty, Kevin D., and Richard V. Ericson. 2000. "The Surveillant Assemblage." The British Journal of Sociology 51 (4): 605-22. https://doi.org/10.1080/00071310020015280. . 2007. "The New Politics of Surveillance and Visibility." In The New Politics of Surveillance and Visibility, edited by Kevin D. Haggerty and Richard V. Ericson, 3-34. Toronto; Buffalo ; London: University of Toronto Press.

Hier, Sean P. 2003. "Probing the Surveillant Assemblage: On the Dialectics of Surveillance Practices as Processes of Social Control." Surveillance \& Society 1 (3): 399-411. https://doi.org/10.24908/ss.v1i3.3347.

Hine, Christine. 2000. Virtual Ethnography. London ; Thousand Oaks: SAGE Publications Ltd. 
2017. “From Virtual Ethnography to the Embedded, Embodied, Everyday Internet." In The Routledge Companion to Digital Ethnography, edited by Larissa Hjorth, Heather Horst, Anne Galloway, and Genevieve Bell, 21-28. New York ; London: Routledge. https://doi.org/10.4324/9781315673974.

Hirschman, Albert O. 1970. Exit, Voice, and Loyalty: Responses to Decline in Firms, Organizations, and States. Cambridge, Massachusetts: Harvard University Press.

. 1993. "Exit, Voice, and the Fate of the German Democratic Republic: An Essay in Conceptual History.” World Politics 45 (2): 173-202. https:// doi.org/10.2307/2950657.

Howard, Philip N., and Muzammil M. Hussain. 2013. Democracy's Fourth Wave?: Digital Media and the Arab Spring. Oxford; New York: Oxford University Press.

Ilyushina, Mary. 2019. "Russia Rolls out Its 'sovereign Internet.' Is It Building a Digital Iron Curtain?” CNN. November 1, 2019. https://www.cnn.com/2019/11/01/tech/russiainternet-law/index.html.

Jonson, Lena. 2015. Art and Protest in Putin's Russia. Abingdon, Oxon; New York: Routledge. Jost, John T., Pablo Barberá, Richard Bonneau, Melanie Langer, Megan Metzger, Jonathan Nagler, Joanna Sterling, and Joshua A. Tucker. 2018. "How Social Media Facilitates Political Protest: Information, Motivation, and Social Networks." Political Psychology 39 (S1): 85-118. https://doi.org/10.1111/pops.12478.

Kamikadzedead. 2019. "Navalny and a Bunch of Idiots." YouTube. March 24, 2019. https://www.youtube.com/watch?v=aekpMcCSBYc.

- 2020. "Glamorous Bitch Escaped without Punishment, or Why We Need a People's Court." YouTube. January 21, 2020.

https://www.youtube.com/watch?v=eea_Qnm_6yU.

Karnaukh, Maria. 2015. "Google Ready for New Personal Data Law; Facebook Holds Off." August 31, 2015.

https://www.rbth.com/science_and_tech/2015/08/31/google_ready_for_new_persona 1_data_law_facebook_holds_off_48869.html.

Kavkazky Uzel. 2017. “Alexander Valov Complains to ECHR about FSB Officers.” March 6, 2017. https://www.kavkaz-uzel.eu/articles/298762/.

Kitchin, Rob. 1998. “Towards Geographies of Cyberspace.” Progress in Human Geography 22 (3): 385-406. https://doi.org/10.1191/030913298668331585.

Kitchin, Rob, Denis Linehan, Cian O'Callaghan, and Philip Lawton. 2013. "Public Geographies through Social Media.” Dialogues in Human Geography 3 (1): 56-72. https://doi.org/10.1177/2043820613486432.

Kosovan, Alexander. 2016. "Why Does the Law on Offending Believers Exist, and How Does It Work." Snob.Ru. July 20, 2016. https://snob.ru/entry/49206/.

Kozkina, Anna. 2018. “'An Ambulance Will Be Called When He Lies in a Pool of Blood.' Prison Protest by Sochi Journalist.” Mediazona. June 25, 2018. https://zona.media/article/2018/06/25/blogsochi.

Kravchenko, Svetlana. 2016. "Valov Rejects Charges of Organizing Protest in Sochi." Kavkazky Uzel. June 6, 2016. https://www.kavkaz-uzel.eu/articles/283715/.

Levada Center. 2019. "Protest potential.” December 2, 2019. https://www.levada.ru/2019/12/02/protestnyj-potentsial-10/. 
2020. "Sources of Information." September 28, 2020.

https://www.levada.ru/2020/09/28/ggh/.

Lim, Merlyna. 2015. "A CyberUrban Space Odyssey. The Spatiality of Contemporary Social Movements.” New Geographies 07 (October): 117-23.

Lipman, Maria, Anna Kachkaeva, and Michael Poyker. 2018. "Media in Russia: Between Modernization and Monopoly." In The New Autocracy: Information, Politics, and Policy in Putin's Russia, edited by Daniel Treisman, 159-90. Washington, D.C: Brookings Institution Press.

Lipman, Maria, and Tanya Lokot. 2019. "Disconnecting the Russian Internet: Implications of the New ‘Digital Sovereignty’ Bill.” February 21, 2019. http://www.ponarseurasia.org/pointcounter/article/disconnecting-russian-internet-implications-new-digital-sovereignty-bill.

Lokot, Tetyana. 2018. "Be Safe or Be Seen? How Russian Activists Negotiate Visibility and Security in Online Resistance Practices.” Surveillance \& Society 16 (3): 332-46. https://doi.org/10.24908/ss.v16i3.6967.

MacAskill, Ewen. 2014. "Putin Calls Internet a 'CIA Project' Renewing Fears of Web Breakup." The Guardian, April 24, 2014, sec. World news. https://www.theguardian.com/world/2014/apr/24/vladimir-putin-web-breakupinternet-cia.

MacKinnon, Rebecca. 2011. “China's 'Networked Authoritarianism.” Journal of Democracy 22 (2): 32-46. https://doi.org/10.1353/jod.2011.0033.

Merrill, Samuel, and Johan Pries. 2019. "Translocalising and Relocalising Antifascist Struggles: From \#KämpaShowan to \#KämpaMalmö.”' Antipode 51 (1): 248-70. https://doi.org/10.1111/anti.12451.

Merrill, Samuel, Shanti Sumartojo, Angharad Closs Stephens, and Martin Coward. 2020. "Togetherness after Terror: The More or Less Digital Commemorative Public Atmospheres of the Manchester Arena Bombing's First Anniversary." Environment and Planning D: Society and Space 38 (3): 546-66. https://doi.org/10.1177/0263775819901146.

Michaelsen, Marcus. 2018. "Exit and Voice in a Digital Age: Iran's Exiled Activists and the Authoritarian State.” Globalizations 15 (2): 248-64. https://doi.org/10.1080/14747731.2016.1263078.

Motuznaya, Maria. 2018a. “@la72la: ‘Hi, My Name Is Masha, I'm 23 Years Old, and I'm an Extremist."' Twitter. July 23, 2018. https://twitter.com/la72la/status/1021358749636866048. . 2018b. “@la72la: 'Take Care of Yourselves and Your Familes, and If You Can, Get out of This Country :).” Twitter. July 23, 2018. https://twitter.com/La72La/status/1021441380181213186?s=20.

Murakami Wood, David. 2013. "What Is Global Surveillance? Towards a Relational Political Economy of the Global Surveillant Assemblage." Geoforum 49 (October): 317-26. https://doi.org/10.1016/j.geoforum.2013.07.001.

Nemtsova, Zhanna. 2018. "Blogger kamikadzedead: I'm doing propaganda for a revolution in the minds of Russians.” DW.COM. March 14, 2018. https://bit.ly/2MSeBvS.

Novaya Gazeta. 2019. "Roskomnadzor denied media registration licenses to Gudkov, FBK, OpenMedia." Novayagazeta.ru. April 24, 2019. https://www.novayagazeta.ru/news/2019/04/24/151174-roskomnadzor-ne-vydallitsenziyu-na-registratsiyu-smi-dmitriyu-gudkovu-fbk-i-otkrytym-media. 
Novie Izvestiya. 2017. "Experts Say the RuNet Is Dramatically Losing Freedom.” October 17, 2017. https:// newizv.ru/news/society/17-10-2017/eksperty-runet-stremitelno-teryaetsvobodu.

OUKRF. 2020. “Complete Legal Text: Criminal Code of the Russian Federation.” 2020. http://oukrf.ru/.

Penney, Joel, and Caroline Dadas. 2014. "(Re)Tweeting in the Service of Protest: Digital Composition and Circulation in the Occupy Wall Street Movement." New Media \& Society 16 (1): 74-90. https:// doi.org/10.1177/1461444813479593.

Popkov, Alexander. 2018. "Chief editor of Sochi website detained on suspicion of extorting State Duma deputy." Meduza. January 20, 2018.

https://meduza.io/news/2018/01/20/glavreda-sochinskogo-sayta-zaderzhali-popodozreniyu-v-vymogatelstve-u-deputata-gosdumy.

Pospieszna, Paulina, and Aleksandra Galus. 2019. “'Liberation Technology' or 'Net Delusion’? Civic Activists' Perceptions of Social Media as a Platform for Civic Activism in Belarus and Ukraine." Europe-Asia Studies 71 (10): 1664-84. https://doi.org/10.1080/09668136.2019.1623176.

Qiang, Xiao. 2019. "President XI's Surveillance State.” Journal of Democracy 30 (1): 53-67. https://doi.org/10.1353/jod.2019.0004.

Radchenko, Darya, Dina Pisarevskaya, and Irina Ksenofontova. 2012. "The Logic of Virtual Protest: The Week After the 2011 Elections." Forum for Anthropology and Culture, no. 7:117.

RBC. 2017. "Roskomnadzor waits on blocking YouTube for 'Open Russia."' RBC. December 4, 2017. https://www.rbc.ru/rbcfreenews/5a327a6d9a794744bd6803bb.

Rivera, Sharon Werning, and James D. Bryan. 2019. "Understanding the Sources of AntiAmericanism in the Russian Elite.” Post-Soviet Affairs 35 (5-6): 376-92. https://doi.org/10.1080/1060586X.2019.1662194.

Roth, Andrew. 2019. "Russian Protesters Demand End to Political Crackdown." The Guardian, September 29, 2019, sec. World news.

https://www.theguardian.com/world/2019/sep/29/russia-protesters-demand-end-topolitical-crackdown.

Ruijgrok, Kris. 2017. "From the Web to the Streets: Internet and Protests under Authoritarian Regimes.” Democratization 24 (3): 498-520. https://doi.org/10.1080/13510347.2016.1223630.

Russian Federal State Statistics Service. 2020. "Population of Sochi: Numbers, Composition, Dynamics, Information.” 2020. https:// rosinfostat.ru/naselenie-goroda-sochi/\#i.

Shields, Rob. 2003. The Virtual. Abingdon, Oxon ; New York: Routledge. https://doi.org/10.4324/9780203987186.

Skibo, Daria. 2017. "Five Years of Russia’s Foreign Agent Law.” OpenDemocracy. August 14, 2017. https://www.opendemocracy.net/en/odr/five-years-of-russia-s-foreign-agentlaw/.

Soldatov, Andrei, and Irina Borogan. 2015. The Red Web: The Struggle Between Russia's Digital Dictators and the New Online Revolutionaries. 1st edition. New York: PublicAffairs.

Steinholt, Yngvar B. 2013. "Kitten Heresy: Lost Contexts of Pussy Riot's Punk Prayer.” Popular Music and Society 36 (1): 120-24. https://doi.org/10.1080/03007766.2012.735084. 
Thrift, Nigel. 1996. "New Urban Eras and Old Technological Fears: Reconfiguring the Goodwill of Electronic Things." Urban Studies 33 (8): 1463-93. https://doi.org/10.1080/0042098966754.

Tkacheva, Olesya. 2019. "Digital Media and Perceptions of the United States among the Russian Elite, 2004-2016.” Post-Soviet Affairs 35 (5-6): 393-405. https://doi.org/10.1080/1060586X.2019.1662195.

Topak, Özgün. 2017. “The Making of a Totalitarian Surveillance Machine: Surveillance in Turkey Under AKP Rule." Surveillance \& Society 15 (3/4): 535-42. https://doi.org/10.24908/ss.v15i3/4.6614. . 2019. "The Authoritarian Surveillant Assemblage: Authoritarian State Surveillance in Turkey." Security Dialogue 50 (5): 454-72. https://doi.org/10.1177/0967010619850336.

Treisman, Daniel, ed. 2018. The New Autocracy: Information, Politics, and Policy in Putin's Russia. Washington, D.C: Brookings Institution Press.

TV Rain. 2017. “Kamikadzedead Explains Why He Left Russia.” December 25, 2017. https:/ /www.youtube.com/watch?v=ijA8ZdL2VPQ.

Varlamov, Ilya. 2018a. “How I Was Detained by FSB.” March 29, 2018. https://www.youtube.com/watch?v=20Swva3WaaU. - 2018b. "How the FSB Detained Me Twice in Volgograd.” June 20, 2018. https://www.youtube.com/watch?v=A_1uwlYnKgE. . 2019. Non-Tourist St. Petersburg. https://www.youtube.com/watch?v=89f-V3AVY9w. . 2020. "A Golden Ass: Ekaterinburg Authorities Want to Make the City Shitty." February 9, 2020. https://www.youtube.com/watch?v=t7NpTTER-dM.

Vlavo, Fidele. 2012. "“Click Here to Protest' Electronic Civil Disobedience and the Imaginaire of Virtual Activism.” Cybercultures, January, 125-48. https://doi.org/10.1163/9789401208536_009.

Voronina, Olga G. 2013. "Pussy Riot Steal the Stage in the Moscow Cathedral of Christ the Saviour: Punk Prayer on Trial Online and in Court." Digital Icons: Studies in Russian, Eurasian and Central European New Media 9: 69-85.

White, David. 2015. "Political Opposition in Russia: The Challenges of Mobilisation and the Political-Civil Society Nexus." East European Politics 31 (3): 314-25. https://doi.org/10.1080/21599165.2014.990628.

Williams, Matthew L, Pete Burnap, and Luke Sloan. 2017. “Towards an Ethical Framework for Publishing Twitter Data in Social Research: Taking into Account Users' Views, Online Context and Algorithmic Estimation.” Sociology 51 (6): 1149-68. https://doi.org/10.1177/0038038517708140.

Zhitkova, Valeriya. 2019. "Christmas Trees, Lunch, and YouTube: How the Blogger Varlamov Became a Serial Entrepreneur and a Multimillionaire.” Forbes.Ru. October 11, 2019. https://www.forbes.ru/karera-i-svoy-biznes/385149-elki-lanchi-i-youtube-kak-blogervarlamov-prevratilsya-v-seriynogo. 